\title{
Hubungan Iklim, Kepadatan Nyamuk Anopheles dan Kejadian Penyakit Malaria
}

\author{
SUWITO $^{1)}$, UPIK KESUMAWATI HADI ${ }^{2)}$, SINGGIH H SIGIT ${ }^{2)}$, \\ DAN SUPRATMAN SUKOWATI ${ }^{3)}$ \\ ${ }^{1)}$ Sekolah Tinggi Kesehatan Abdi Nusa Pangkalpinang, \\ Subdit Pengendalian Vektor Depkes RI \\ ${ }^{2)}$ Bagian Parasitologi dan Entomologi Kesehatan, Departemen Ilmu Penyakit Hewan dan \\ Kesehatan Masyarakat Veteriner, FKH IPB \\ ${ }^{3)}$ Puslitbang Ekologi dan Status Kesehatan Depkes RI
}

(diterima Januari 2010, disetujui Maret 2010)

\begin{abstract}
Correlations of Climate, Anopheles Density and Malaria Incidence. Districts of South Lampung and Pesawaran are malaria endemic areas. The purpose of this study was to analyze the relationship between climate, Anopheles density and malaria incidence. Mosquito collections were caught by human landing collection all night 06:00 PM-06:00 AM. The relation of climate with Anopheles density and Anopheles density with malaria incidence were analysed by Pearson Product Moment test. The Anopheles bite all night, peaks with 02:00-04:00 AM, outdoor bitings were more frequent than indoor biting. There were relationships between relative humidity and rain fall with Anopheles density, and Anopheles density with malaria incidence one month later.
\end{abstract}

KEY WORD: Climate, Anopheles density, malaria insidence

\section{PENDAHULUAN}

Indonesia merupakan negara kepulauan yang memiliki iklim tropis yang heterogen dan rentan terhadap dampak perubahan iklim regional dan global. Perubahan iklim makro dan mikro dapat mempengaruhi penyebaran penyakit menular, termasuk penyakit tular vektor nyamuk. Peningkatan kelembaban dan curah hujan berbanding lurus dengan peningkatan kepadatan nyamuk, sedangkan suhu mempunyai batas optimum bagi perkembangbiakan nyamuk antara $25-27^{\circ} \mathrm{C}$ (Epstein et al. 1998). Penelitian mengenai simulasi matematis transmisi malaria yang dikaitkan dengan perubahan iklim sangat membantu deteksi dini merebaknya kasus malaria (Martens 1997).

Sektor kesehatan merupakan salah satu sektor yang rentan terhadap dampak perubahan iklim, sehingga antisipasi perubahan iklim terhadap sektor kesehatan di Indonesia dan lingkungannya merupakan hal yang sangat penting. Sukowati (2008) menyatakan di Indonesia faktor iklim berpengaruh signifikan terhadap risiko penularan penyakit tular vektor seperti 
demam berdarah dan malaria. Model matematis menunjukkan bahwa peningkatan suhu global $3{ }^{\circ} \mathrm{C}$ menjelang tahun 2100 dapat meningkatkan penyakit malaria 50-80 juta per tahun (Martens 1997).

Penyakit malaria di Lampung disinyalir berkorelasi dengan kepadatan nyamuk Anopheles sebagai vektor, sebagaimana pernyataan Rozendal (1997) bahwa banyaknya vektor akan berkorelasi positif dengan tingginya kasus penyakit. Kepadatan populasi vektor yang tinggi dapat meningkatkan kontak vektor yang infektif terhadap manusia (Mc. Kelvey et al. 1991). Nyamuk Anopheles yang telah ditemukan kontak dengan manusia di Lampung Selatan antara lain A. sundaicus, A. subpictus, $A$. vagus, $A$. indefinitus, $A$. nigerrimus, $A$. peditaeniatus, A. kochi, A. Barbirostris, A. annullaris, A. separatus, A. tessellatus dan $A$. aconitus (Idram Idris et al. 1999).

Kepadatan vektor yang tinggi menjadikan Lampung Selatan daerah endemis malaria sepanjang tahun. Jumlah penyakit malaria berdasarkan hasil penghitungan angka parasit malaria atau annual parasite incidence (API) perseribu penduduk tahun 2005 sebesar 15,5\%, tahun 2006 sebesar $7,4 \%$, tahun 2007 sebesar 12\% dan tahun 9,9\% (Depkes 2009).

Berdasarkan latar belakang tersebut, maka penelitian iklim menjadi penting untuk memprediksi peningkat- an atau penurunan kepadatan nyamuk Anopheles serta kaitannya dengan peningkatan dan penurunan penyakit malaria. Adapun tujuan penelitian ini adalah untuk mengetahui hubungan iklim dengan kepadatan nyamuk Anopheles serta untuk mengetahui hubungan kepadatan nyamuk Anopheles dengan kejadian penyakit malaria.

\section{BAHAN DAN METODE}

\section{Tempat dan Waktu Penelitian}

Penelitian dilaksanakan di Lampung Selatan dan Pesawaran yang merupakan wilayah kategori kasus sedang malaria (medium case incidence/MCI) di Indonesia. Tepatnya di dua kecamatan endemis malaria status kasus tinggi malaria (high incidence area/HIA), yaitu Kecamatan Rajabasa dan Kecamatan Padangcermin. Penelitian dilaksanakan selama satu tahun, mulai September 2008 sampai dengan September 2009.

\section{Bahan dan Alat}

Bahan dan peralatan yang digunakan yaitu mikroskop stereo, aspirator, kloroform dan kuesioner terstruktur mengenai iklim, kepadatan nyamuk dan penyakit malaria.

\section{Pengamatan Iklim}

Data iklim diperoleh dari data sekunder, yang diambil dari Badan Meteorologi Klimatologi dan Geofisika (BMKG) Raden Intan Lampung Selatan, meliputi suhu udara, ke- 
lembaban udara dan curah hujan. Suhu dan kelembaban udara dirata-ratakan tiap bulannya. Nilai indeks curah hujan bulanan dihitung dengan mengalikan jumlah curah hujan perbulan dengan hari hujan perbulan, lalu dibagi dengan jumlah hari pada bulan yang bersangkutan.

\section{Penangkapan Nyamuk Malam Hari}

Kepadatan nyamuk diperoleh dari hasil penangkapan nyamuk yang hinggap di badan pada malam hari pukul 18:00-06:00, dengan metode HLC (human landing collection). Digunakan tiga rumah sebagai lokasi penangkapan, dimana masing-masing rumah terdapat seorang penangkap, masing-masing di luar dan di dalam rumah. Dalam tiap jamnya bekerja selama 45 menit dan istirahat 15 menit. HLC dilakukan selama satu tahun, dimana tiap bulannya empat malam di Kecamatan Rajabasa dan empat malam di Padangcermin. Nyamuk yang hinggap di badan ditangkap menggunakan aspirator, kemudian nyamuk dibunuh mengunakan cloroform, dihitung jumlahnya dan diidentifikasi spesiesnya menggunakan mikroskop stereo. Identifikasi nyamuk menggunakan kunci identifikasi nyamuk Anopheles dari O'Connor dan Soepanto (1999). Kepadatan nyamuk Anopheles menghisap darah per orang per malam dihitung berdasarkan nilai man bitting rate (MBR). Nilai MBR didapat dari jumlah nyamuk Anopheles (spesies tertentu) yang tertangkap per malam dibagi jumlah penangkap. Karena per orang per jamnya menangkap 45 menit, berarti permalam menangkap sembilan jam, maka dikalikan 12/9.

$$
M B R=\frac{\text { Enyamuk }(\text { permalam })}{\text { Spenangkap }} \times \frac{12}{9}
$$

\section{Pengamatan Penyakit Malaria}

Jumlah kasus malaria diperoleh dari data sekunder, yang diambil dari Puskesmas di wilayah Kecamatan Rajabasa dan Padangcermin, yaitu Puskesmas Waymuli, Hanura dan Padangcermin.

\section{Analisis Data}

Kepadatan nyamuk Anopheles menggigit per orang per malam (MBR) dirata-ratakan tiap bulannya dan disajikan dalam bentuk grafik selama satu tahun, di dalam dan di luar rumah. Fluktuasi suhu udara, kelembaban udara dan indeks curah hujan disajikan dalam bentuk grafik selama satu tahun. Untuk mengetahui hubungan iklim dengan kepadatan nyamuk Anopheles, dilakukan uji korelasi pearson product moment pada $\alpha=0,05$. Jika terdapat hubungan bermakna, maka diteruskan dengan uji regresi linier sederhana untuk mengetahui seberapa besar pengaruh iklim terhadap kepadatan nyamuk Anopheles, dengan mencari nilai kooefesien determinasi $\left(r^{2}\right)$. Data kasus malaria selama satu tahun 


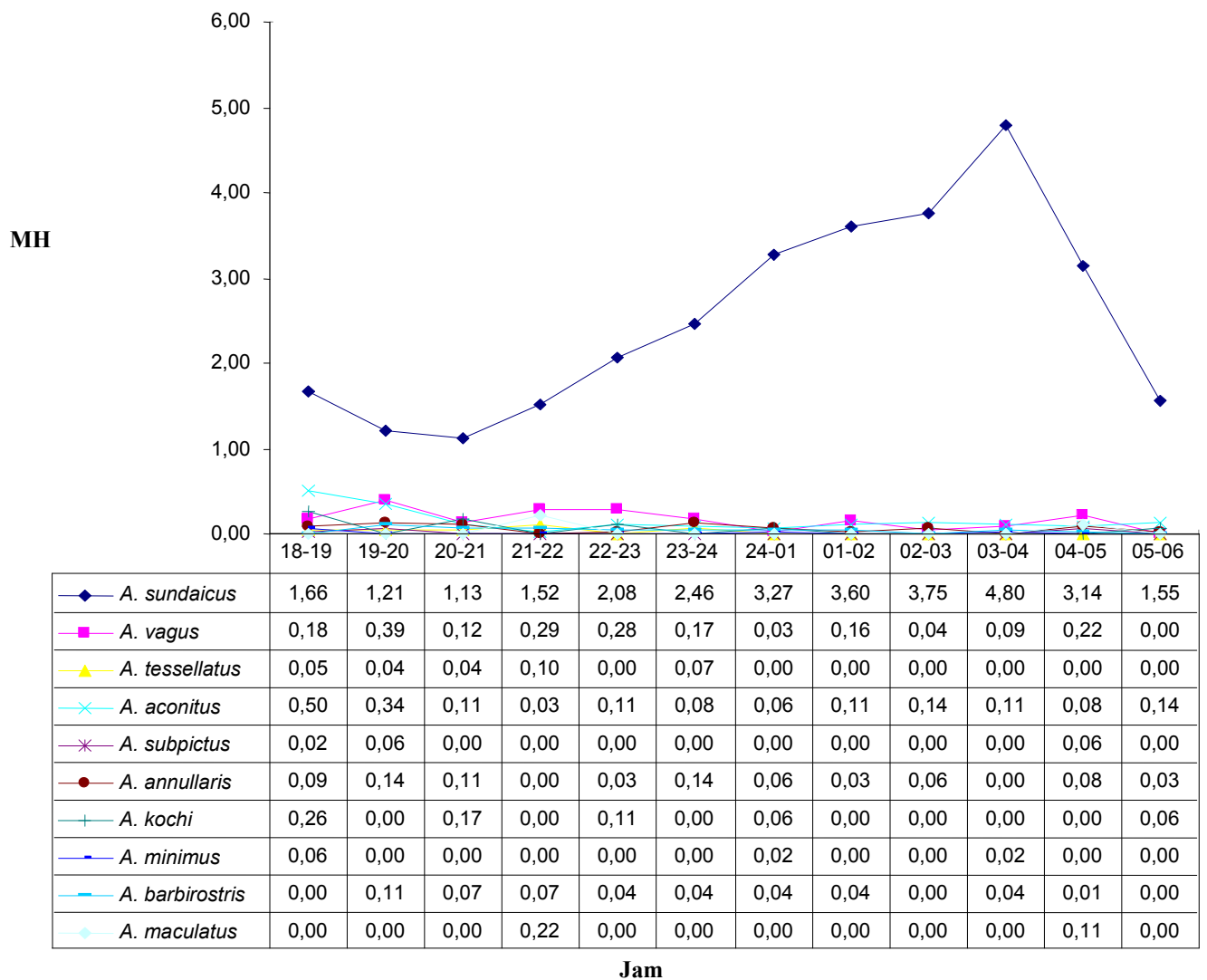

Gambar 1. Fluktuasi kepadatan Anopheles per orang per jam (MHD) di Rajabasa, Lampung Selatan

disajikan dalam bentuk grafik. Untuk mengetahui hubungan kepadatan Anopheles dengan kasus malaria menggunakan uji korelasi pearson product moment pada $\alpha=0,05$. Jika terdapat hubungan bermakna, maka dilanjutkan dengan uji regresi linier sederhana untuk mengetahui seberapa besar pengaruh kepadatan nyamuk Anopheles terhadap kasus malaria, dengan mencari nilai kooefesien determinasi $\left(r^{2}\right)$.

\section{HASIL DAN PEMBAHASAN}

Wilayah Kecamatan Rajabasa didapatkan 10 spesies Anopheles yang kontak dengan manusia, yaitu $A$. sundaicus, $A$. vagus, $A$. tessellatus, $A$. aconitus, A. subpictus, A. annularis, A. kochi, A. minimus, A. barbirostris dan A. maculatus. Wilayah Kecamatan Padangcermin didapatkan delapan spesies Anopheles yang kontak dengan manusia, yaitu $A$. sundaicus, $A$. subpictus, A. barbirostris, A. kochi, A. aconitus, A. tessellatus, A. vagus dan 


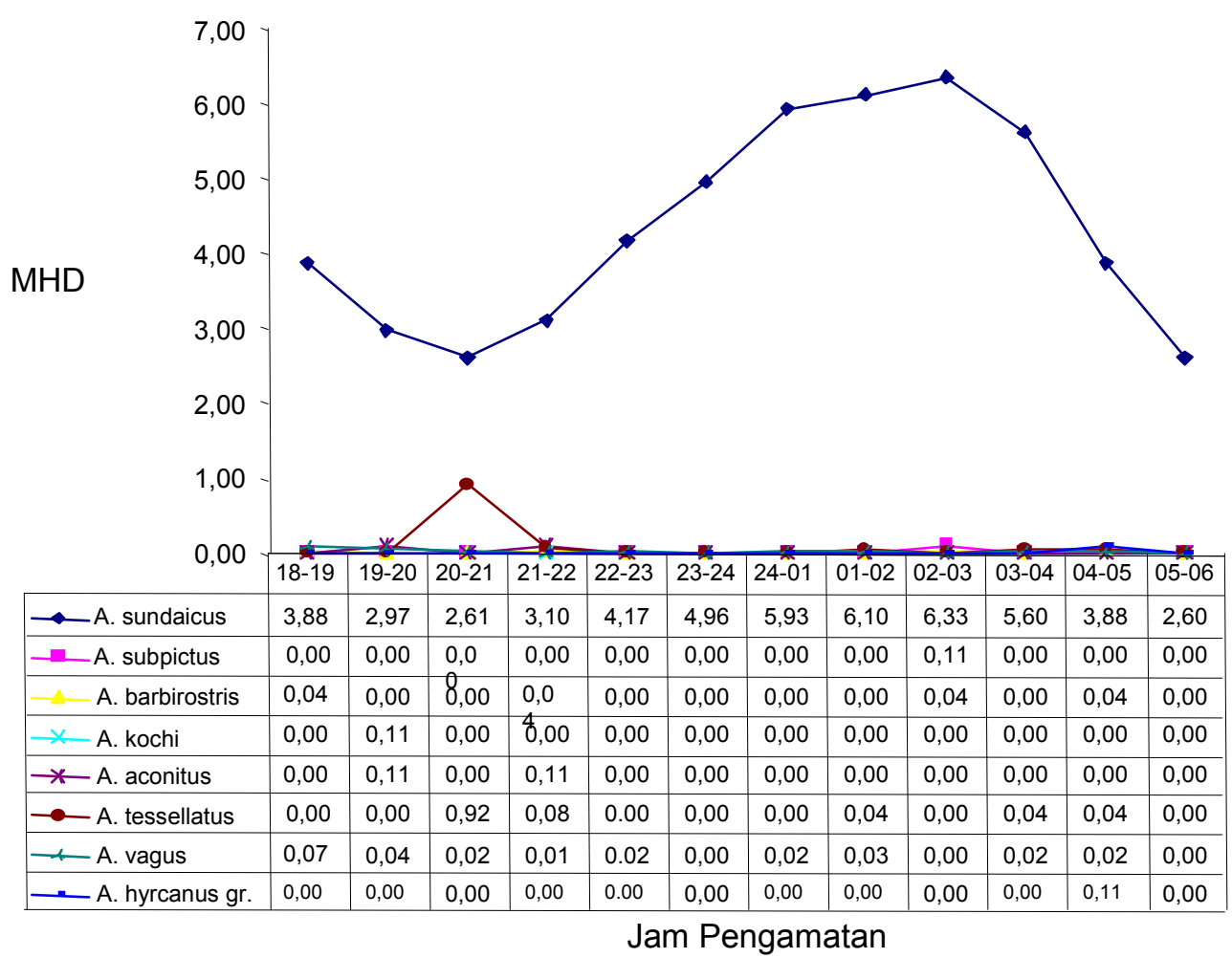

Gambar 2. Fluktuasi kepadatan Anopheles per orang per jam (MHD) di Padangcermin-Pesawaran

A. hyrcanus group. Nyamuk $A$. sundaicus merupakan spesies dominan di Kecamatan Rajabasa dan Padangcermin, sebagaimana ditunjukkan dari angka gigitan per orang per jam (MHD) sangat tinggi melebihi spesies lainnya (Gambar 1 dan Gambar 2).

Kepadatan nyamuk Anopheles per orang per malam (MBR) menunjukkan Anopheles menghisap darah sepanjang bulan, tertinggi pada Desember, dengan rata-rata 108 gigitan per orang per malam pada Desember. Nyamuk Anopheles lebih banyak menghisap darah di luar rumah dibandingkan dengan di dalam rumah (Gambar 3).
Suhu udara berkisar antara 25,60-27,30

${ }^{\circ} \mathrm{C}$. Rata-rata suhu udara terendah pada Desember dan tertinggi pada September. Kepadatan Anopheles meningkat pada kisaran suhu $26-26,5{ }^{\circ} \mathrm{C}$, mencapai puncaknya pada suhu 26,1 ${ }^{\circ} \mathrm{C}$. Pada suhu udara di atas $27{ }^{\circ} \mathrm{C}$ grafik kepadatan Anopheles menurun. Hasil uji korelasi pearson pada $\alpha=0,05$, didapatkan nilai $\mathrm{p}=0,757 \quad(\mathrm{p}>0,05)$ (Gambar 4), artinya tidak ada hubungan bermakna suhu udara dengan kepadatan nyamuk Anopheles per orang per malam (MBR). 


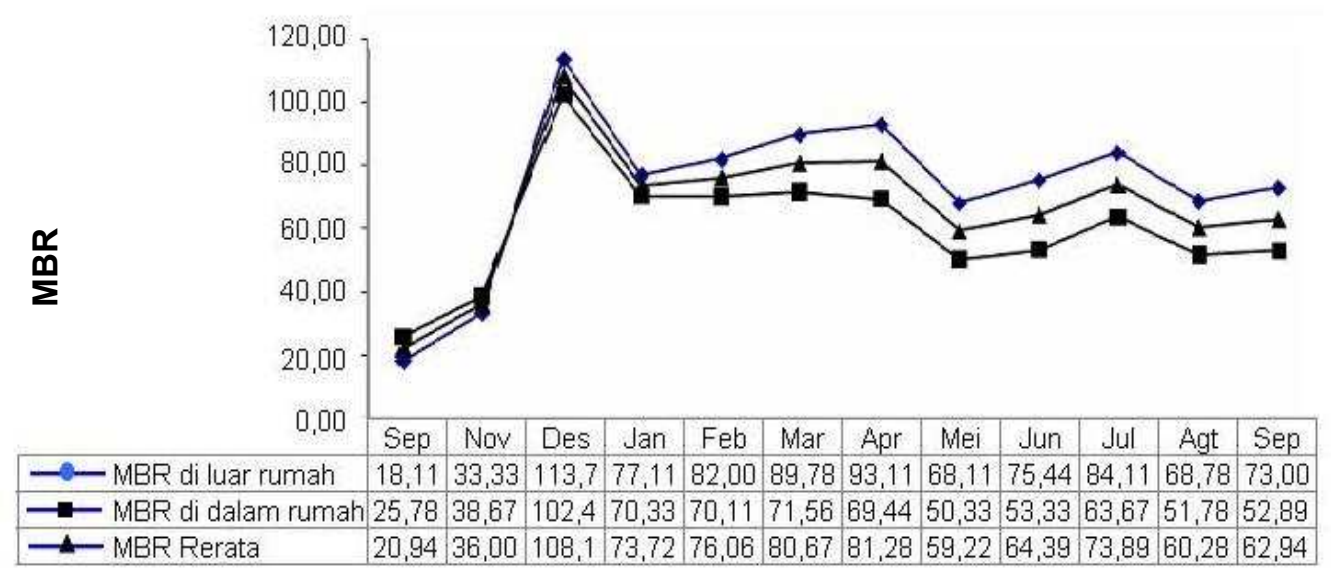

\section{Bulan Pengamatan}

Gambar 3. Fluktuasi kepadatan Anopheles per orang per malam (MBR) di Rajabasa, Lampung Selatan dan Padangcermin-Pesawaran

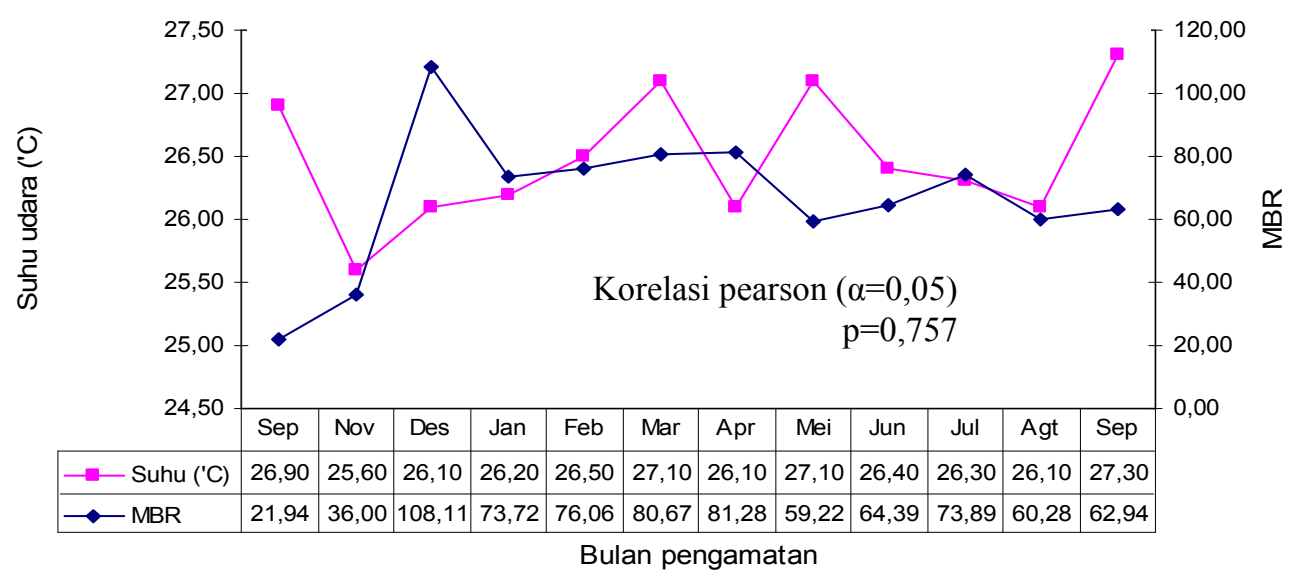

Gambar 4. Hubungan suhu udara dengan kepadatan Anopheles (MBR) di Rajabasa, Lampung Selatan dan Padangcermin-Pesawaran

Kelembaban udara berfluktuasi, dengan rata-rata tertinggi pada Desember sebesar $84,30 \%$ dan terendah pada Agustus sebesar 76\%. Kelembaban udara mempunyai hubungan bermakna dengan kepadatan nyamuk Anopheles per orang per malam (MBR). Hal ini dibuktikan berdasarkan uji statistik korelasi pearson pada $\alpha=0,05$ didapatkan nilai $p=0,026(p<0,05)$. Nilai koefesien determinasi sebesar 0,405, artinya kepadatan Anopheles 40,5\% dipengaruhi oleh kelembaban udara, selebihnya 59,5\% oleh faktor lain di luar kelembaban udara (Gambar 5). 


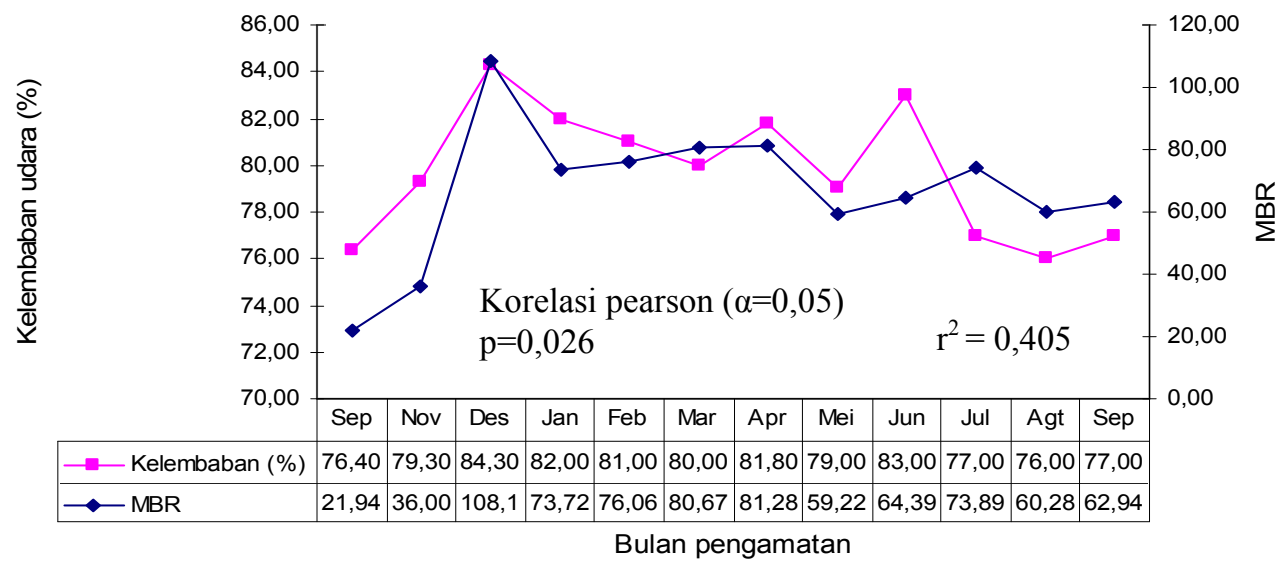

Gambar 5. Hubungan kelembaban udara dengan kepadatan Anopheles (MBR) di Padangcermin-Pesawaran

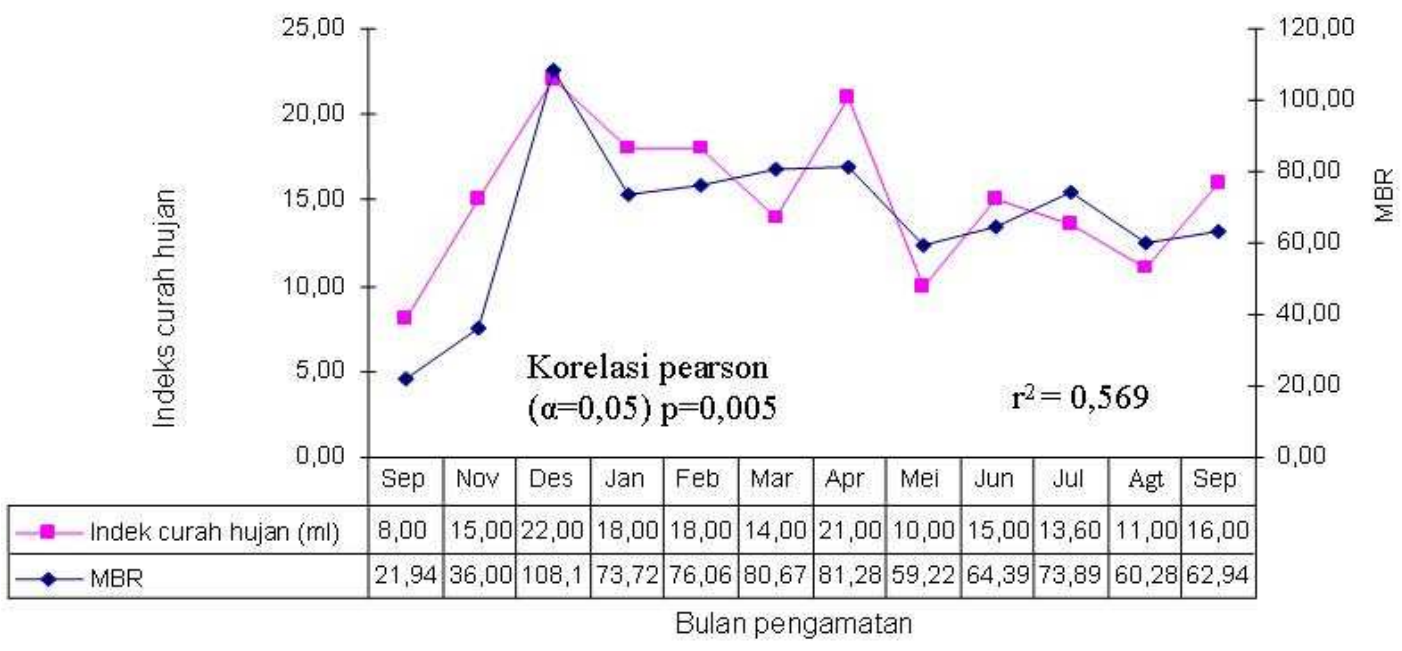

Gambar 6. Hubungan indeks curah hujan dengan kepadatan Anopheles (MBR) di Rajabasa, Lampung Selatan dan Padangcermin-Pesawaran

Curah hujan berfluktuasi pada tiap bulannya, fluktuasi indeks curah hujan tertinggi pada Desember sebesar $22 \mathrm{ml}$ dan terendah pada Mei sebesar $10 \mathrm{ml}$. Hasil perhitungan statistik hubungan antara indeks curah hujan dengan kepadatan nyamuk Anopheles pada $\alpha=0,05$ didapatkan nilai $\mathrm{p}=0,005$ $(p<0,05)$, artinya ada hubungan bermakna indeks curah hujan dengan kepadatan nyamuk Anopheles per orang per malam (MBR). Koefesien determinasi menunjukkan nilai 0,569 , artinya kepadatan nyamuk Anopheles $56,9 \%$ disebabkan oleh curah hujan (Gambar 6).

Kepadatan nyamuk Anopheles dikaitkan dengan penyakit malaria, menunjukkan tidak ada hubungan bermakna kepadatan Anopheles dengan 
kasus malaria $(\mathrm{p}=0,901)$ (Gambar 7). Namun, pada saat kepadatan Anopheles dihubungkan dengan kasus malaria satu bulan berikutnya, didapatkan nilai $\mathrm{p}=0,021(\mathrm{p}<0,05)$, artinya ada hubungan bermakna kepadatan Anopheles dengan kasus malaria satu bulan berikutnya. Hubunganya positif kuat $(\rho=0,681)$, semakin tinggi kepadatan nyamuk per orang per malam (MBR) maka semakin besar kasus malaria pada bulan berikutnya (Gambar 8).

Hasil penangkapan malam hari metode HLC mendapatkan 11 spesies Anopheles, yaitu A. sundaicus, $A$. vagus, A. tessellatus, A. aconitus, A. subpictus, A. annularis, A. kochi, A. minimus, A. barbirostris, A. maculatus, dan $A$. hyrcanus group. Spesies $A$. sundaicus merupakan spesies dominan menghisap darah sepanjang malam mulai dari pukul 18:00-06:00, dengan puncak kepadatan pukul 03:00-04:00 di Rajabasa dan 02:00-03:00 di
Padangcermin. Jumlah kepadatan per orang per jam di luar rumah selalu lebih tinggi dibandingkan dengan di dalam rumah. Hasil ini serupa dengan temuan Sukowati dan Shinta (2009), bahwa $A$. sundaicus aktif menghisap darah manusia sepanjang malam dengan puncak kepadatan antara pukul 02:00-03:00, kepadatan di luar rumah lebih banyak dibandingkan di dalam rumah.

Mardiana et al. (2007) menyatakan aktivitas menghisap darah $A$. sundaicus lebih banyak di luar rumah dengan puncak kepadatan pukul 01.00-02.00, sedangkan di dalam rumah puncak kepadatan pukul 24.00-01.00. Joshi et al. (1977) menyatakan A. aconitus lebih banyak menghisap darah di luar rumah dari pada di dalam rumah, puncak kepadatan tertinggi pada tengah malam. Berdasarkan aktivitas menghisap darah A. sundaicus, bahwa

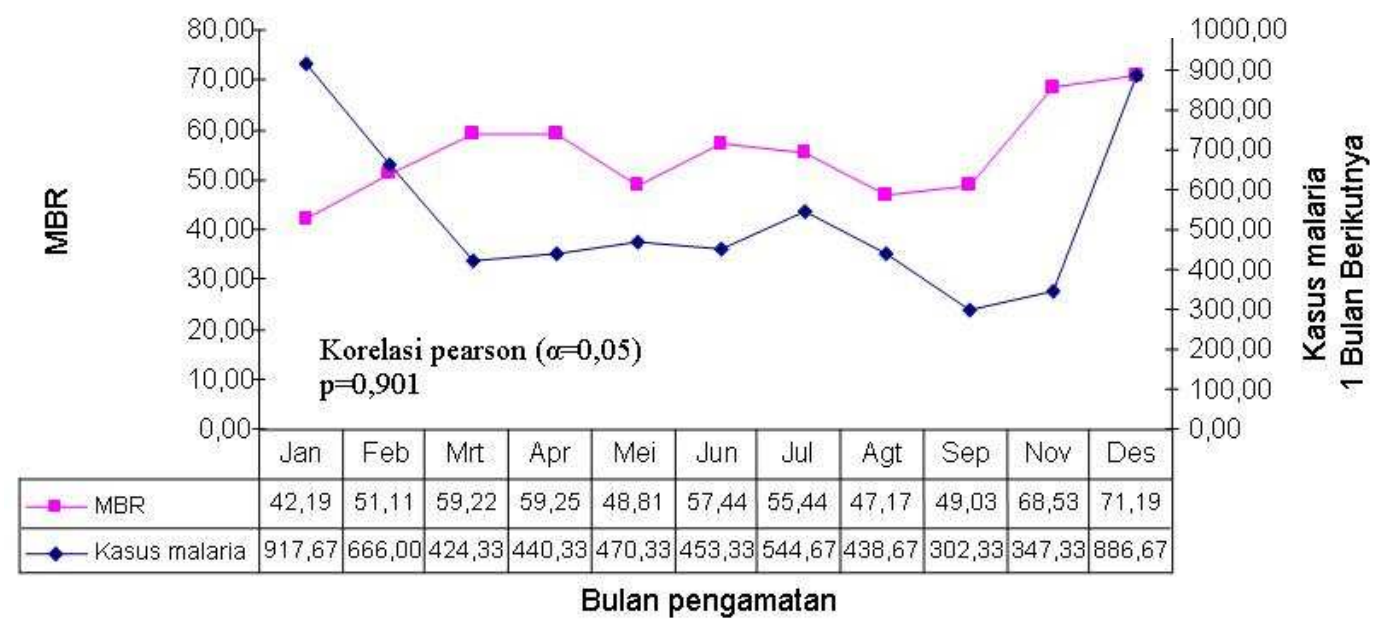

Gambar 7. Hubungan kepadatan Anopheles (MBR) dengan kasus malaria di Rajabasa, Lampung Selatan dan Padangcermin-Pesawaran 


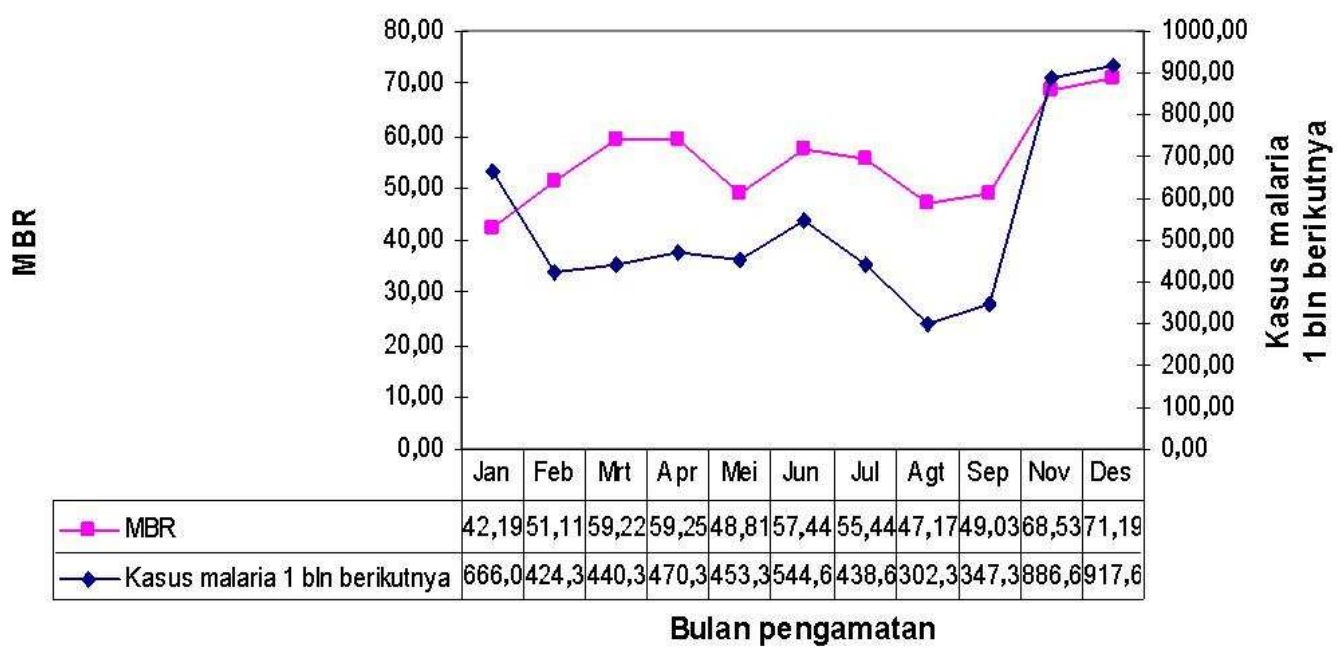

Gambar 8. Hubungan kepadatan Anopheles (MBR) dengan kasus malaria (satu bulan berikutnya) di Rajabasa, Lampung Selatan dan PadangcerminPesawaran

penularan malaria di Rajabasa dan meningkatkan kasus (Rozendal 1997),

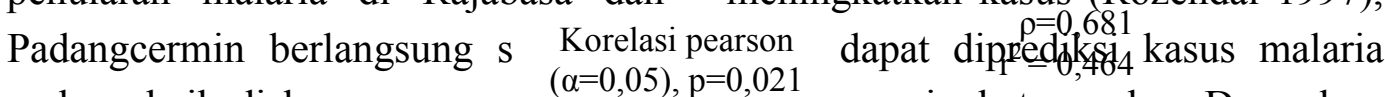
malam, baik di luar maupun us (adam $\stackrel{(\alpha=0,05),}{p=0,021}$ akan meningkat pada Desember, rumah. Meskipun dari hasil pe- dengan anggapan daya tahan tubuh nangkapan menunjukkan nyamuk lebih masyarakat stabil setiap bulan. banyak menghisap darah di luar rumah. Akan tetapi, apabila pada malam hari tidak mendapatkan orang di luar rumah, maka nyamuk akan masuk ke dalam rumah untuk mencari darah (Depkes 1999).

Penelitian ini mempunyai kelebihan dibanding dengan penelitian lainnya yang ada di Indonesia, karena data kepadatan nyamuk Anopheles yang diperoleh berturut-turut setiap bulan selama satu tahun, belum pernah didapatkan oleh penelitian lainnya. Nyamuk Anopheles menghisap darah sepanjang bulan, kepadatan per orang per malam tertinggi pada Desember. Besarnya jumlah nyamuk vektor yang menghisap darah manusia akan
Kepadatan Anopheles per orang per malam dipengaruhi oleh kelembaban udara dan curah hujan. Hasil perhitungan statistik kelembaban udara mempunyai hubungan bermakna dengan kepadatan Anopheles per orang per malam $(\mathrm{p}=0,025)$. Kepadatan Anopheles 40,5\% dipengaruhi oleh kelembaban udara. Kelembaban udara adalah jumlah uap air yang terdapat dalam udara. Uap air di udara sebagian besar berasal dari penguapan air laut. Lampung Selatan dan Pesawaran merupakan daerah pantai berbatasan dengan laut. Pada daerah pantai kelembaban udara relatif lebih tinggi, disebabkan penguapan air laut relatif besar. Kelembaban mempengaruhi ke- 
langsungan hidup dan kebiasaan nyamuk menghisap. Kelembaban yang rendah akan memperpendek umur nyamuk, sebaliknya kelembaban tinggi memperpanjang umur nyamuk. Pada kelembaban yang lebih tinggi, nyamuk akan menjadi lebih aktif dan lebih sering menggigit (Gunawan 2000). Peningkatan kelembaban udara dan curah hujan berbanding lurus dengan peningkatan kepadatan nyamuk (Epstein et al. 1998).

Curah hujan berhubungan bermakna dengan kepadatan Anopheles $(\mathrm{p}=0,005)$. Kepadatan Anopheles per orang per malam 56,9\% dipengaruhi oleh curah hujan. Hasil ini serupa dengan pernyataan Mardiana dan Munif (2009), bahwa kepadatan nyamuk Anopheles di Sukabumi mempunyai hubungan positif dengan curah hujan. Epstein el at. (1998) menyatakan semakin tinggi curah hujan akan menaikan kepadatan nyamuk, demikian juga sebaliknya rendahnya curah hujan mengurangi kepadatan nyamuk. Adanya hujan akan menambah jumlah dan jenis genangan air, yang sebelumnya hanya sedikit atau tidak ada pada musim kemarau. Keberadaan tambak terbengkalai, kobakan dan kubangan menjadi lebih banyak, bak benur (terbengkalai) yang kering menjadi berisikan air, kondisi air lagun dan rawa-rawa menjadi lebih payau. Kondisi perairan ini merupakan habitat yang disenangi oleh $A$. sundaicus untuk perkembangan larva. Semakin banyak habitat perkembangbiakan mempermudah nyamuk meletakkan telur, sehingga kepadatan nyamuk semakin tinggi. Hujan yang diselingi dengan cuaca panas akan meningkatkan berkembangbiaknya Anopheles vektor (Mendoza dan Oliveira 1996).

Kepadatan Anopheles mempunyai hubungan bermakna dengan jumlah kasus malaria satu bulan berikutnya $(p=0,021)$. Hubunganya positif kuat $(\rho=0,681)$, semakin tinggi kepadatan Anopheles per orang per malam maka semakin besar kasus malaria pada bulan berikutnya. Dengan kata lain, terjadinya peningkatan kepadatan Anopheles pada bulan ini, peningkatan kasus malaria akan terjadi satu bulan berikutnya. Hasil ini sesuai dengan masa inkubasi intrinsik parasit malaria, mulai dari masuknya parasit ke dalam tubuh manusia sampai dengan timbulnya gejala klinis Plasmodium falciparum membutuhkan waktu 8-11 hari (Garcia \& Brucher 1996), P. vivax membutuhkan waktu 12-17 hari (Nadesul 1998). Kebiasaan masyarakat datang berobat ke Puskesmas setelah menggigil beberapa hari dan tidak membaik setelah minum obat warung. Pencatatan kasus malaria yang dilakukan oleh Puskesmas melebihi waktu masa inkubasi penyakit, karena pasien datang bukan pada gejala awal, melainkan sering kali pasien datang pada kondisi lebih parah. Jumlah kasus malaria sebulan mendatang 46,4\% disebabkan oleh kepadatan Anopheles 
pada bulan sekarang. Hasil penelitian ini serupa dengan hasil penelitian Mardiana dan Munif (2009), menyatakan bahwa A. aconitus di Purworejo mempunyai hubungan positif dengan insiden malaria, dengan nilai $r^{2}=$ 0,491 .

\section{KESIMPULAN}

Nyamuk $A$. sundaicus merupakan spesies dominan di Kecamatan Rajabasa dan Padangcermin. Suhu udara tidak mempunyai hubungan bermakna dengan kepadatan nyamuk Anopheles. Kelembaban udara dan curah hujan mempunyai hubungan bermakna dengan kepadatan nyamuk Anopheles, sedangkan kepadatan nyamuk Anopheles mempunyai hubungan bermakna dengan kasus malaria satu bulan berikutnya.

\section{UCAPAN TERIMA KASIH}

Penulis mengucakan terima kasih kepada Muspida Kabupaten Lampung Selatan dan Pesawaran, mulai dari Bupati, Camat dan Kepada Desa atas izin dan kemudahan menggunakan lokasi penelitian. Kepada Kepala Dinas Kesehatan Lampung Selatan dan Pesawaran, Pimpinan Puskesmas Waymuli, Hanura dan Padangcermin terima kasih atas bantuan pelaksanaan penelitian. Khususnya kepada pihak malaria transmission concource (MT-C) Indonesia terima kasih atas dana penelitian yang telah diberikan.

\section{DAFTAR PUSTAKA}

[Depkes] Departemen Kesehatan. 1999. Modul Epidemiologi Malaria. Jakarta : Ditjen P2M\&PL.

[Depkes] Departemen Kesehatan. 2009. Penemuan Penderita Malaria Provinsi Lampung. Jakarta : Ditjen PP\&PL.

Epstein PR, Diaz HR, Elias S, Grabherr G, Graham NE, Martens WJM, Thomson EM, Susskind J. (ED). 1998. Biological and physical signs of climate change : focused on mosquitoborne diseases. Bul Amer Meterol Soc 79 : 409-17.

Gracia SL, Brucher DA. 1996. Diagnostic Medical Parasitology. Los Angeles: UCLA Medical Center.

Gunawan S. 2000. Epidemiologi Malaria. Jakarta : EGC.

Idram-Idris NS, Sudomo M, Sujitno. 1999. Fauna Anopheles di daerah pantai hutan mangrove Kecamatan Padang Cermin Lampung Selatan. Bul Penel Kes 32 (2) : 49-61.

Joshi P, Self LS, Usman S, Pant CP, Nelson MJ, Supalin. 1977. Ecological studies on Anopheles aconitus in Semarang area of Central Java. Indonesia. WHO/ $\mathrm{VBC} / 77.677$.

Mardiana, Munif A. 2009. Hubungan antara kepadatan vektor Anopheles aconitus dan insiden 
malaria di daerah endemik di Kabupaten Sukabumi Jawa Barat. Jur Ekol Kes 8 (1) : 901-914.

Mardiana, Sukowati S, Wigati RA. 2007. Beberapa aspek perilaku nyamuk Anopheles sundaicus di Kecamatan Sumur Kabupaten Pandeglang. J Ekol Kes 6 (3) : 621-627.

Martens WJM. 1997. Malaria and climate change. enviromental health perspectives. University of Limburg, Maastricht, The Netherland. $97: 103-116$.

Mc.Kelvey JJ, Eldridge BE, Maramorosch K. 1991. Vector of Disease Agents Interaction with Plants, Animal and Man. New York: Praeger Publisheres, CBC Educational and Professional Publising a division of CBC, Inc. 521 Fith Avenue.

Mendoza CF, Oliveira RLD. 1996. Bionomic of $A$. aquasalis curry 1932, in Guarai, State of Rio de Janerio, Southeastern Brazil. I Seasonal distribution and parity retes. Mem Ins Cruz 91 (3): 265270.

Nadesul H. 1998. Penyebab, Pencegahan dan Pengobatan Malaria. Jakarta : Puspa Swara.

O'connor CT, Soepanto A. 1999. Kunci Bergambar untuk Anopheles Betina dari Indonesia. Jakarta : Ditjen P2M\&PL Depkes.

Rozendal JA. 1997. Vector control, Methods for use by individuals and communities. Genewa: WHO.

Sukowati S. 2008. Masalah Keragaman Spesies Vektor Malaria dan Cara Pengendalianya di Indonesia. Orasi Pengukuhan Profesor Riset Bidang Biologi Lingkungan. Jakarta : Badan Litbangkes Depkes.

Sukowati S, Shinta. 2009. Habitat perkembangbiakan dan aktivitas menggigit nyamuk Anopheles sundaicus dan Anopheles subpictus di Purworejo, Jawa Tengah. $J$ Ekol Kes. 8 (1) : 915-925. 